Research Article

\title{
Evaluation of Fournier's gangrene severity index in the management of Fournier's gangrene: a retrospective study
}

\author{
Shashirekha C. A., Pramod T.*, Nagaraj K. N., Harish Kumar, Rakesh N.
}

Department of General Surgery, Sri Devaraj Urs Medical College, Tamaka, Kolar, India

Received: 15 October 2015

Revised: 20 October 2015

Accepted: 16 December 2015

\section{*Correspondence:}

Dr. Pramod T.,

E-mail: pramodthejoram@gmail.com

Copyright: () the author(s), publisher and licensee Medip Academy. This is an open-access article distributed under the terms of the Creative Commons Attribution Non-Commercial License, which permits unrestricted non-commercial use, distribution, and reproduction in any medium, provided the original work is properly cited.

\section{ABSTRACT}

Background: Demonstration of the usefulness of Fournier's gangrene severity index in the management of Fournier's gangrene.

Methods: A retrospective study of all the patients admitted to the hospital with Fournier's gangrene was included in the study in the year 2012. Fournier's gangrene was diagnosed by history and clinical examination. Details of the patients were obtained from the hospital register. FGSI was calculated using 9 parameters; heart rate, temperature, respiratory rate, sodium, potassium, serum creatinine, serum bicarbonate, leukocyte count and hematocrit. The score was graded $0 \pm 4$.

Results: The details of the patients were tabulated. The age of the patients ranged from 25 to 60 years (mean 44 years). All were male patients. The mean duration of disease before treatment was 7.5 days (ranged from 5 to 10 days). Three patients had diabetes and other patients did not have any risk factors. One among the diabetic was obese. Six patients had infection of scrotum and one patient had infection in with scrotal abscess needed I and D. Tissue and pus was sent for culture and sensitivity. Appropriate antibiotics were started covering aerobic and anaerobic organisms. Few patients required repeated debridement to minimize burden of infection. Antibiotics were changed according to culture sensitivity report. With repeated debridement and antibiotics, wound epithelized to surface. Secondary suturing was done as a corrective procedure to close the defect in 6 patients and split skin grafting was done in one patient as the defect was larger in size. FGSI was calculated in all patients. Five patients presented with necrotic patch, progressing rapidly needed necrosectomy initially and other patient presented treatment lasted for average of 45 days ranging from 38 to 55 days. All patients were cured with no mortality.

Conclusions: Necrotizing fasciitis of the perineum and genitalia is a severe and rapidly progressive condition with considerable morbidity and mortality. Survival can be improved in a patient with Fournier's gangrene by FGSI, aggressive surgical and medical management. FGSI is very useful in assessing the severity of the disease and high mortality associated with it. Continuous monitoring of all the parameters is essential for a good outcome, therefore reducing the high, mortality and morbidity of the condition.

Keywords: Fournier's gangrene, Fournier's gangrene severity index, Necrotizing fasciitis, Radical debridement, Necrosectomy

\section{INTRODUCTION}

Fournier's gangrene is a rapidly progressing myonecrosis usually involving perineum, genitals and perianal region. It was initially described by Baurienne in 1764 but it is named after French dermatologist Jean Alfred Fournier, who in 1883 described a syndrome of unexplained gangrene in the penis and scrotum in 5 young old boy with no other source of infection., 
It is common in age group between 35 to 65 years, although it is been reported in younger age group. It's rare in females. Fournier's gangrene most commonly involves perineum, genitals and perianal region but can also involve anterior abdominal wall and upper limbs. ${ }^{1,2}$ Currently these infections are classified based on anatomic site, causative agent and extension or invasion of infection.

The most common organisms isolated from these infections include group A streptococci, coagulase negative Staphylococci, S. aures, S. epidermidis and Clostridium species. ${ }^{2,3}$ Gram negative organisms include E. coli, Enterobacter, Pseudomonas, Proteus and Bacteriodes. Polymicrobial infection tends to be more common than single infection.
The risk factors include diabetes mellitus, obesity, malnutrition, immunosuppression, renal failure, steroid use, leukemia.

The mortality rate is high (10 to $30 \%$ ) and it could be as high as $70 \%$. Laor et al. developed the Fournier's gangrene severity index (FGSI) using 9 parameters (Table 1). FGSI is very useful in assessing the severity of the disease and mortality associated with it.

The management includes early recognition of infection, antibiotics, debridement, flap closure and supportive measures. $^{3}$

Table 1: Fournier's gangrene severity index parameters.

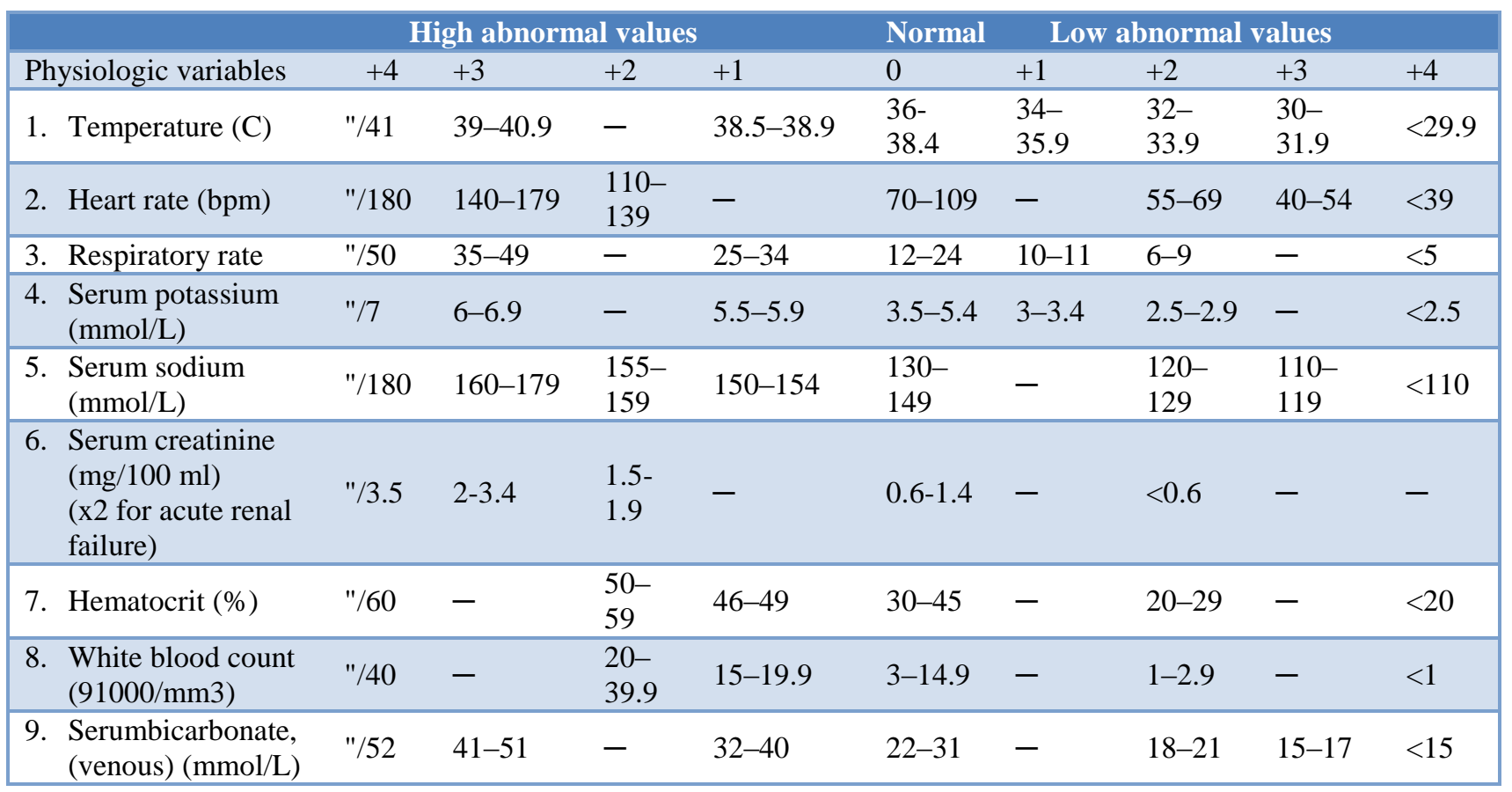

\section{METHODS}

In a period between January 2011 to September 2012, we treated 7 patients with Fournier's gangrene. They were aged between 25 to 60 years. All were male patients. Out of 7 patients, 3 patients had diabetes mellitus; other 4 patients did not have any risk factors. The 6 patients had necrotizing infection of scrotum and one patient had infection in medial side of thigh extending to genitals. FGSI was calculated using 9 parameters - heart rate, temperature, respiratory rate, sodium, potassium, serum creatinine, serum bicarbonate, leukocyte count and hematocrit. The score was graded $0 \pm 4$.

\section{RESULTS}

The details of the patients were tabulated. The age of the patients ranged from 25 to 60 years (mean 44 years). All were male patients. The mean duration of disease before treatment was 7.5 days (ranged from 5 to 10 days). Three patients had diabetes and other patients did not have any risk factors. One among the diabetic was obese. Six patients had infection of scrotum and one patient had infection in medial side of thigh. FGSI was calculated in all patients.

Five patients presented with necrotic patch, progressing rapidly which needed necrosectomy initially and other patient presented with scrotal abscess which needed incision and drainage. Tissue and pus was sent for culture 
and sensitivity. Appropriate antibiotics were started covering aerobic and anaerobic organisms. Few patients required repeated debridement to minimize burden of infection. Antibiotics were changed according to culture sensitivity report. With repeated debridement and antibiotics, wound epithelialized to surface. Secondary suturing was done as a corrective procedure to close the defect in 6 patients and split skin grafting was done in one patient as the defect was larger in size. The treatment lasted for average of 45 days ranging from 38 to 55 days. All patients were cured with no mortality.

Table 2: Details of the patients.

\begin{tabular}{|c|c|c|c|c|c|c|c|}
\hline Patient & $\mathbf{A}$ & B & $\mathbf{C}$ & D & $\mathbf{E}$ & $\mathbf{F}$ & $\mathbf{G}$ \\
\hline Age (years) & 45 & 45 & 48 & 38 & 25 & 60 & 48 \\
\hline Sex & Male & Male & Male & Male & Male & Male & Male \\
\hline $\begin{array}{l}\text { Duration of } \\
\text { disease (day) }\end{array}$ & 7 & 10 & 5 & 8 & 6 & 8 & 9 \\
\hline Other factors & $\begin{array}{l}\text { Diabetes } \\
\text { obesity }\end{array}$ & - & Diabetes & - & - & Diabetes & - \\
\hline Microbiology & E. coli & $\begin{array}{l}\text { Enteroco } \\
\text { cus }\end{array}$ & $\begin{array}{l}\text { Klebsiella } \\
\text { Enterococus }\end{array}$ & S. aures & MRSA & E. coli & E. coli \\
\hline Antibiotics & $\begin{array}{l}\text { Amikacin } \\
\text { Pipercillin }\end{array}$ & $\begin{array}{l}\text { Vancom } \\
\text { ycin } \\
\text { Linezoid }\end{array}$ & $\begin{array}{l}\text { Amikacin } \\
\text { Chloramphe } \\
\text { nicol } \\
\text { Meropenem }\end{array}$ & $\begin{array}{l}\text { Vancomyc } \\
\text { in } \\
\text { Linezoid }\end{array}$ & $\begin{array}{l}\text { Vancomyc } \\
\text { in }\end{array}$ & Amikacin & pipercillin \\
\hline Procedure & $\begin{array}{l}\text { Necrosecto } \\
\text { my }\end{array}$ & $\begin{array}{l}\text { Necrosec } \\
\text { tomy }\end{array}$ & I and D & $\begin{array}{l}\text { Necrosecto } \\
\text { my }\end{array}$ & $\begin{array}{l}\text { Necrosecto } \\
\text { my }\end{array}$ & necrosectomy & necrosectomy \\
\hline $\begin{array}{l}\text { Treatment } \\
\text { time (days) }\end{array}$ & 45 & 42 & 55 & 38 & 38 & 47 & 42 \\
\hline $\begin{array}{l}\text { Definitive } \\
\text { procedure }\end{array}$ & $\begin{array}{l}\text { Secondary } \\
\text { suturing }\end{array}$ & SSG & $\begin{array}{l}\text { Secondary } \\
\text { suturing }\end{array}$ & $\begin{array}{l}\text { Secondary } \\
\text { suturing }\end{array}$ & $\begin{array}{l}\text { Secondary } \\
\text { suturing }\end{array}$ & $\begin{array}{l}\text { Secondary } \\
\text { suturing }\end{array}$ & $\begin{array}{l}\text { Secondary } \\
\text { suturing }\end{array}$ \\
\hline Out come & Cured & Cured & Cured & Cured & cured & Cured & Cured \\
\hline
\end{tabular}

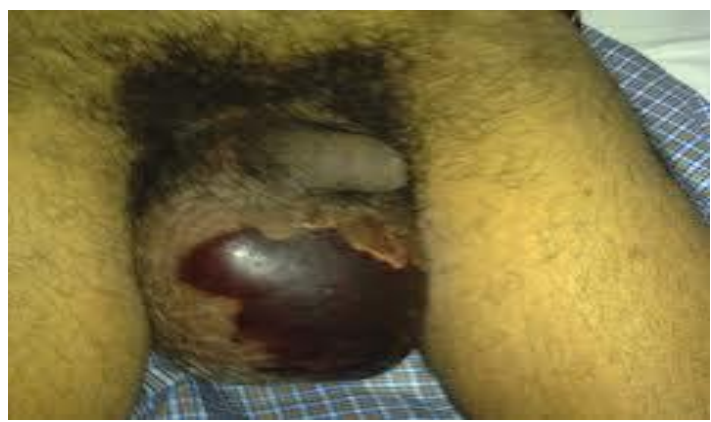

Figure 1: Fournier's gangrene of scrotum.

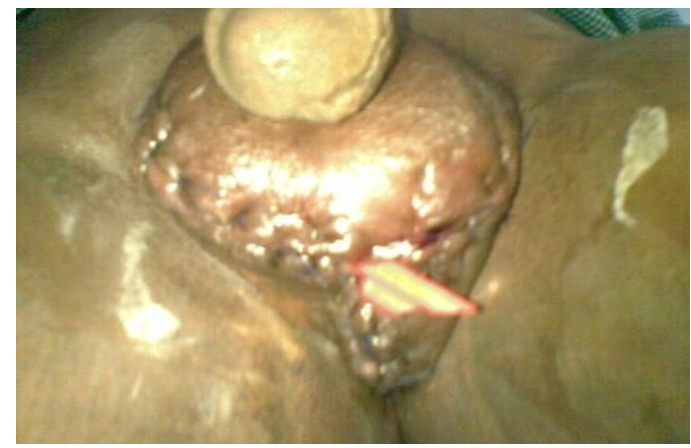

Figure 2: Secondary suturing after debridement.

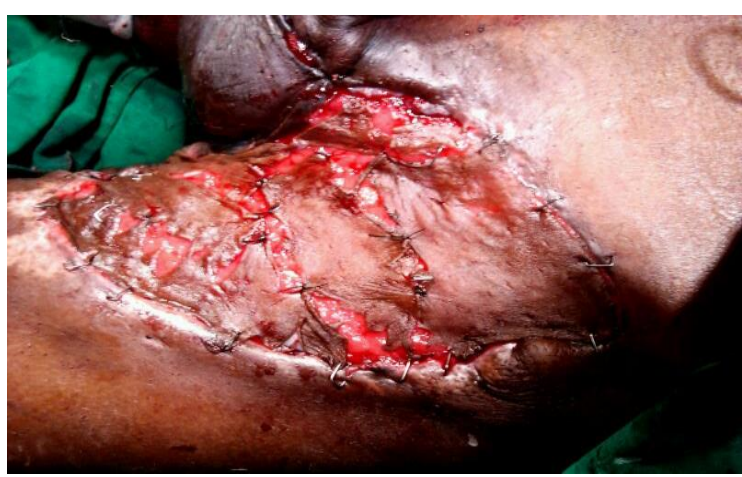

Figure 3: Split skin graft covering the wound.

\section{DISCUSSION}

Fournier's gangrene, which is not so rare as is generally considered, is still associated with a high morbidity and mortality, which can be reduced only by improving medical awareness and early treatment both, of the primary cause and of necrotizing fasciitis. ${ }^{3,4}$

It is no more considered as an idiopathic disease as studies have shown few predisposing factors which cause this disease. It is more common among males although it 
can occur in females and children. ${ }^{3,7}$ In our study, all patients were male with mean age of 44 years. The interval from onset of clinical symptoms to the initial surgical intervention appears to be the most important prognostic factor with a significant impact on outcome. A typical patient presents 2-7 days after initiation of symptoms, in our study the mean duration of presentation was 7.5 days. $^{4,6}$

The comorbid conditions found in our study were diabetes mellitus and obesity, which are considered as comorbid conditions in other studies as well. ${ }^{5,8}$ In our study we found fournier's gangrene to be a polymicrobial infection with Enterococcus and E coli being the most common organism found. This finding is also supported by other studies.

The main aspects of treatment of Fournier's gangrene are resuscitation, broad spectrum intravenous antibiotics and radical surgical debridement followed by multiple debridements if needed. ${ }^{6,9}$ This was the strategy in all our cases.

Use of hyperbaric oxygen, honey application, enzymatic debridement and penrose drains are shown to be useful in the literature. ${ }^{7-9}$ In our study, all patients were treated with broad spectrum antibiotics and debridements.

Our study showed skin can be closed after multiple debridements and also split skin grafting can be used to close the skin defect. In our study, secondary suturing was done as a corrective procedure to close the defect in six patients and split skin grafting was done in one patient as the defect was larger in size.

The mortality rate of fournier's gangrene ranges from 0 to $67 \%$ but in the majority of studies it is 10 to $30 \% .^{7,9} \mathrm{In}$ our study all patients were cured of disease.

\section{CONCLUSION}

Necrotizing fasciitis of the perineum and genitalia is a severe and rapidly progressive condition with considerable morbidity and mortality. Survival can be improved in a patient with Fournier's gangrene by FGSI, aggressive surgical and medical management. FGSI is very useful in assessing the severity of the disease and mortality associated with it. Continuous monitoring of all the parameters is essential for a good outcome, therefore reducing the high mortality and morbidity of the condition.

The key to a more favorable outcome includes: a high index of suspicion, prompt fluid resuscitation, rapid initiation of broad-spectrum intravenous antibiotic therapy, urgent surgical intervention with radical debridement and frequent debridement needed.

Funding: No funding sources

Conflict of interest: None declared

Ethical approval: The study was approved by the institutional ethics committee

\section{REFERENCES}

1. Gurdal M, Yucebas E, Tekin A, Beysel M, AslanR, Sengor F. Predisposing factors and treatmentoutcome in Fournier's gangrene: analysis of 28cases. UrolInt. 2003;70:286-90.

2. Papachristodoulou AJ, Zofrafos GN, Papastratis G, Papavassiliou V, Markopoulos CJ, Mandrekas D, et al. Fournier's gangrene: still highlylethal. Langenbecks Arch Chir. 1997;382:15-8.

3. Ferreira PC, Reis JC, Amarante JM, Silva AC, Pinho CJ, Oliveira IC, et al. Fournier'sgangrene: a review of 43 reconstructive cases. PlastReconstr Surg. 2007;119(1):175-84.

4. Norton KS, Johnson LW, Perry T, Perry KH, Sehon JK, Zibari GB. Management of Fournier's gangrene: an eleven year retrospective analysis of early recognition, diagnosis, and treatment. Am Surg. 2002;68:709-13.

5. Dahm P, Roland FH, Vaslef SN, Moon RE, Price DT, Georgiade GS. Outcome analysis in patients with primary necrotizing fasciitis of the male genitalia. Urology. 2000;56:31.

6. Hejase MJ, Simonin JE, Bihrle R, Coogan CL. Genital fournier's gangrene: experience with 38patients. Urology. 1996;47:734-9.

7. Chawla SN, Gallop C, Mydlo JH. Fournier's gangrene: an analysis of repeated surgical debridement. Eur Urol. 2003;43:572-5.

8. Gurdal M, Yucebas E, Tekin A, Beysel M, Aslan R, Sengor F. Predisposing factors and treatment outcome in Fournier's gangrene. Analysis of 28 cases. UrolInt. 2003;70:286-90.

9. Yeniyol C, Suelozgen T, Arslan M, RizaAyder A. Fournier's gangrene: experience with 25 patients and use of Fournier's gangrene severity index score. Urology. 2004;64(2):218-22.

Cite this article as: Shashirekha CA, Pramod T, Nagaraj KN, Harish Kumar, Rakesh N. Evaluation of Fournier's gangrene severity index in the management of Fournier's gangrene: a retrospective study. Int Surg J 2016;3:169-72. 